\title{
KONSEP KEARIFAN TEMPATAN MENURUT PERSPEKTIF HUKUM ISLAM
}

\section{The Concept of Local Wisdom in the Islamic Law Perspective}

\author{
Muhammad Ikhlas Rosele*
}

Abdul Karim Ali**

\begin{abstract}
Local wisdom is a widely used concept in social science. It is a concept that describes the roles of identity of a region and society or a small group that affect their life systems. However, the position of this concept in Islamic law is still vague. Hence, this study analyzes the position of local wisdom according to Islamic law perspectives. This study conducted using a qualitative approach by using full library data. The inductive, deductive and comparative methods of analysis are used to obtain the necessary results. The study found that the concept of local wisdom exists and is acknowledged in Islamic law. In addition, the concept of local wisdom is not necessarily understood as 'urf.
\end{abstract}

Keywords: Local Wisdom, 'Urf, Islamic Law, Society, Values

\footnotetext{
* Senior Lecturer, Department of Fiqh and Usul, Academy of Islamic Studies, University of Malaya, ikhlas@um.edu.my

** Associate Professor, Department of Fiqh and Usul, Academy of Islamic Studies, University of Malaya, abdkarim@um.edu.my
} 


\section{PENDAHULUAN}

John K-C. Liu menggambarkan sebuah realiti di perkampungan Chin-Be yang mempunyai satu arca berupa seekor katak yang dipakaikan pakaian seperti perisai komander. Komander pula dalam kepercayaan taoi merupakan golongan yang berada di carta tertinggi. Oleh itu, masyarakat setempat meletakkan komander sebagai rujukan dalam segala hal. Ini menimbulkan persoalan apakah fungsi replika atau patung katak tersebut? Liu secara umumnya menjelaskan';

In this way, individual questions are answered, family disputes are resolved, and community decisions made. The Frog, in the form of an Armored General, dispenses power and resources to keep peace and harmony. Ordinary daily life in this fringe and mundane village continues to revolve around the symbolic figure of the Frog, proprietor of local wisdom in its totality.

Kenyataan tersebut menjelaskan apakah yang dimaksudkan dengan kearifan tempatan melalui satu bentuk perumpamaan. Albantani dan Madkur pula menyatakan kearifan tempatan lazimnya merujuk kepada penduduk asal yang merupakan orang asal kepada sesuatu kawasan dan bukannya datang dari sesuatu tempat yang lain. Justeru, pada peringkat awal difahami kearifan tempatan adalah satu jumlah pengalaman sesuatu masyarakat khusus, uji kaji yang tidak formal dan kefahaman yang mendalam tentang persekitaran yang dikurniakan kepada mereka ${ }^{2}$.

Hal ini sudah tentu menimbulkan persoalan yang luas mengenai konsep kearifan tempatan. Persoalan apakah yang dimaksudkan

1 Liu, J. K-C, "When Professional Knowledge Meets Local Wisdom: A Dilemma in Trans-Cultural Participatory Design." dalam Hou, J., Farncis, M. \& Brightbill, N. (eds.). (Re)constructing Communities Design Participation in the Face of Change, hh. 41-46 (Davis: Centre for Design Research, 2005).

2 Azkia Muharom Albantani \& Ahmad Madkur, "Think Globally, Act Locally: The Strategy of Incorporating Local Wisdom in Foreign Language Teaching in Indonesia," International Journal of Applied Linguistics \& English Literature 7, no. 2 (2018), 2. 
dengan kearifan tempatan dan ruang lingkupnya akan menjadi satu titik kajian yang penting. Tambahan pula dalam dimensi pengajian Islam, kearifan tempatan perlu dijelaskan kedudukan dan posisinya menurut perspektif hukum Syarak.

\section{KONSEP KEARIFAN TEMPATAN}

Kearifan tempatan adalah satu terma ilmu yang dibentuk bagi menjelaskan satu keadaan, budaya dan ilmu bagi sesuatu kawasan atau masyarakat. Dari sudut etimologi, kearifan tempatan mengandungi dua perkataan iaitu kearifan (wisdom) dan tempatan (local). Secara prinsipnya setiap perkataan tersebut perlu difahami untuk mendapat penjelasan makna umum kearifan tempatan. Tempatan bererti lingkungan kawasan dan serantau manakala kearifan adalah seerti dengan hemah ${ }^{3}$.

Kearifan adalah diterjemahkan sebagai wisdom dalam Bahasa Inggeris, menurut Ackoff wisdom terletak di tingkat teratas dalam piramid pengetahuan (knowledge pyramid) seperti berikut;

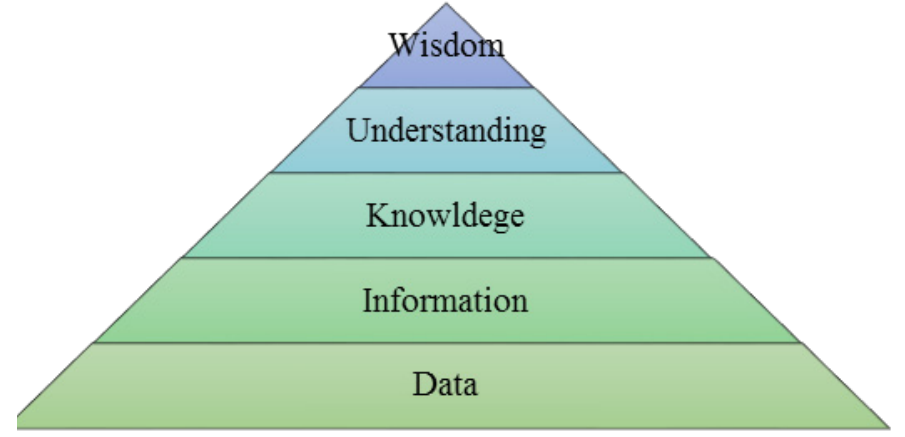

Data terhasil daripada pemerhatian dan pengukuran yang rambang. Maklumat (information) pula terhasil daripada analisis terhadap hubungan dan kaitan antara data, ia mampu untuk menjawab persoalan siapa?, apa?, di mana?, dan bila? Manakala pengetahuan pula terhasil daripada himpunan wajar terhadap

3 Jundiani, "Local Wisdom in the Environmental Protection and Management," dalam IOP Conf. Series: Earth and Environmental Science 175 (UK: IOP Publishing, 2018), 1-5. 
maklumat yang mampu menjawab persoalan bagaimana? Kemudian kefahaman (understanding) pula akan menjawab persoalan mengapa? Di tingkat teratas adalah wisdom yang terbina melalui pengetahuan, komunikasi pengetahuan dengan pengguna dan melalui tindak balas ${ }^{4}$. Menurut Allen pula wisdom adalah sesuatu yang menjangkaui pengetahuan, ia adalah pengetahuan tentang sesuatu pengetahuan, mengetahui apakah pengetahuan yang relevan dan hendak diaplikasikan ${ }^{5}$.

Selanjutnya, apabila melihat konteks kefahaman wisdom adalah merujuk kepada al-hikmah dalam bahasa Arab. Terjemahan tepat kepada wisdom dalam bahasa Arab adalah hikmah dan secara tidak langsung boleh mengetepikan terjemahan lain seperti al- 'urf. Menurut kamus Inggeris-Arab, wisdom adalah merujuk kepada makna hikmah", 'aql dan 'ilm. Manakalah knowledge (yang sering juga dikaitkan dengan wisdom) adalah merujuk kepada makna 'ilm dan $\mathrm{ma}^{\prime}$ rifa $^{7}$. Daripada penjelasan tersebut dapat diringkas secara umum kedudukan ilmu, makrifah dan hikmah sebagaimana berikut;

1. Ma'rifah adalah lebih umum dari ilmu. Ilmu adalah khusus kerana tidak didahului kejahilan, manakala ma'rifah adakalanya didahului kejahilan dan adakalanya tidak didahului kejahilan.

2. Ma'rifah boleh disebut sebagai gambaran sedangkan ilmu adalah pembenaran ${ }^{8}$.

4 Ackoff, R. L., "From data to wisdom," Journal of Applied Systems Analysis 15 (1989), 3-9; Mike Watts, "Explanations and Explaining in Science: You Can't Force People to Understand," in Mike Watts, Debate in Science Education (New York: Routledge, 2014).

5 G. Donald Allen, "Hierarchy of Knowledge: From Data to Wisdom," International Journal of Current Research in Multidisciplinary (IJCRM) 2, no. 1 (2017), 16.

6 Steingass, f. English-Arabic Dictionary for The Use of Both Travelers and Students (London: W.H. Allen \& CO, 1882), 460.

7 Steingass, f. English-Arabic Dictionary for The Use of Both Travelers and Students, 215.

8 Ibn al-Qayyim al-Jawziyyah, Madarij al-Salikin Bayna Manazil Iyyaka Na'bud wa Iyyaka Nasta'in (Dimashq: Dār al-Kitab al'Arabī, 1996), 314-315. 
3. Ilmu merupakan asas hikmah dan tiada hikmah bagi orang yang tidak berilmu?

Al-Hikmah di dalam al-Ta'rifat bererti satu ilmu yang digunakan untuk mencari hakikat sesuatu sebagaimana keadaan sebenarnya yang ada dalam kadar kemampuan manusia. Ia dikategorikan sebagai ilmu teori bukannya ilmu alat. Selain itu, hikmah ditakrifkan sebagai kondisi kekuatan akal dan amali yang seimbang dan tidak berlebihan. Hikmah ini datang dalam tiga makna iaitu kurniaan, ilmu dan perbuatan al-muthallathah seperti matahari dan bulan. ${ }^{10}$

Menariknya al-Sayuti menjelaskan al-hikmah sebagai falsafah begitu juga dengan keterangannya mengenai al-hikmah alnazariyyah sebagai ilmu terhadap apa yang tidak wujud dengan ikhtiar manusia dan al-hikmah al-'amaliyyah sebagai ilmu terhadap apa yang boleh wujud dengan ikhtiar manusia ${ }^{11}$. Ini bermakna hikmah atau wisdom itu boleh terbentuk sama ada dari sudut teori dan pemikiran atau dari sudut perbuatan dan amalan.

Selain itu, Jubran telah menyenaraikan maksud hikmah sebagaimana berikut: ${ }^{12}$

\begin{tabular}{|l|l|}
\hline Masdar kepada hukum & Keadilan \\
\hline Falsafah & Sebab dan 'Illah \\
\hline Ilmu tentang hakikat sesuatu & $\begin{array}{l}\text { Dan kalimah yang digambarkan } \\
\text { dari kepakaran dan pengalaman } \\
\text { (tajribah) yang selari dengan ke- } \\
\text { benaran. }\end{array}$ \\
\hline $\begin{array}{l}\text { Panduan jiwa dan tabiat ma- } \\
\text { nusia dari sifat marah }\end{array}$ & \\
\hline
\end{tabular}

$9 \quad$ Perbahasan ini akan dilanjutkan dalam perbahasan selanjutnya.

10 'Alī bin Muḥammad al-Jurjān̄̄, Al-Ta'rifat (Qāhirah: Dār al-Rayyān li al-Turāth, t.t.), 123.

11 Al-Sayuti, Jalal al-Din, Mu'jam Maqalid al- 'Ulum fi al-Hudud wa al-Rusum (Qāhirah: Maktabah al-Adab, 2004), 130.

12 Jubran Mas'ud, Al-Ra ìd: Mu'jam Lughawiyy 'Asriyy (Bayrūt: Dār al-'Ilm li al-Malayin, 1996), 312. 
Dalam konteks wisdom, pengertian pertama, keempat, kelima dan ketujuh daripada pengertian yang dikemukakan Jubran dilihat bersesuaian. Lantaran itu, sekali lagi dapat difahami dua aspek utama wisdom iaitu satu kerangka pemikiran dan terjemahannya ke dalam tindakan.

Perkaitan tempatan atau local dengan kearifan (kebijaksanaan) atau wisdom juga merupakan sesuatu yang penting. Elemen semasa dan setempat merupakan subjek yang penting dalam ilmu sosiologi bahkan hukum Islam sendiri. Kerana itulah didapati dalam penulisan fiqh dan usul fiqh, elemen setempat menjadi elemen yang perlu ditekankan. Sebagai contohnya, al-Kafrawi menjelaskan ${ }^{13}$;

"Seorang faqih itu tidak boleh jumud dalam satu pendirian yang dipegangnya melalui fatwa, pengajaran, penulisan dan pengkanunan, sedangkan zaman, uruf dan keadaan berubah. Sewajarnya seorang faqih itu meraikan maqāșid al-sharī'ah yang kulli serta matlamatnya yang umum dalam menentukan hukum yang juz $i$. Mengiktiraf perubahan yang dihadapi manusia sama ada disebabkan kerosakan zaman seperti yang digambarkan fuqaha' atau perkembangan masyarakat atau datangnya darurat. Dalam keadaan seperti ini adalah harus bagi fuqaha'itu mengubah fatwanya selaras dengan perubahan zaman, tempat, uruf dan keadaan."

Selaras dengan kenyataan al-Kafrawi tersebut, terdapat satu kaedah yang menjelaskan ${ }^{14}$;

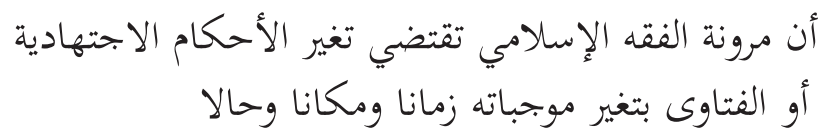

Terjemahan: Keanjalan figh Islam membawa kepada berubahnya hukum ijtihadi atau fatwa dengan

13 As'ad 'Abd al-Ghani al-Kafrawi, Al-Istidlal inda al-Usuliyyin (Qāhirah: Dār al-Salam, 2002), 470-471.

14 'Abd al-Hakim al-Ramili, Taghayyur al-Fatwa fi al-Figh al-Islāmī (Bayrūt: Dār al-Kutub al-'Ilmiyyah, 2016), 46. 
berubahnya masa, tempat dan keadaan.

Setelah itu, penjelasan mengenai maksud kearifan tempatan akan dilakukan sebagai asas untuk memahami kedudukannya dalam hukum Islam. Jundiani menjelaskan makna kearifan tempatan (local wisdom) sebagai satu idea setempat, nilai, sudut pandang yang mana terkandungnya ciri-ciri kebijaksanaan ${ }^{15}$. Kearifan tempatan juga dianggap sebagai satu nilai dan ideologi yang memberi gambaran kehidupan dan cara hidup yang memberi kesan kepada ciri-ciri sebuah kawasan. ${ }^{16}$ Menurut Sesilia Seli, kearifan tempatan adalah usaha manusia yang menggunakan akal budinya untuk memberi tindak balas dan respons kepada sesuatu, objek, peristiwa yang terjadi dalam ruang tertentu. ${ }^{17}$ Supriyanto et al. pula menjelaskan ${ }^{18}$;

"Kearifan lokal digunakan untuk mengindikasikan
adanya suatu konsep bahawa dalam kehidupan so-
sial-budaya lokal terdapat suatu keluhuran, keting-
gian nilai-nilai, kebenaran, kebaikan dan keinda-
han yang dihargai oleh warga masyarakat sehingga
digunakan sebagai panduan atau pedoman untuk
membangun pola hubungan di antara warga atau se-
bagai dasar untuk membangun tujuan hidup mereka
yang ingin direalisasikan."

15 Jundiani, "Local Wisdom in the Environmental Protection and Management," 1-5.

16 Indrayuda, "The Existence of Local Wisdom Value Through Minangkabau Dance Creation Representation in Present Time," HARMONIA: Journal of Arts Research and Education 16, no. 2 (2016), 145.

17 Sesilia Seli, "Tema, Amanat dan Kearifan Tempatan dalam Cerita $\mathrm{Ne}$ 'Baruakng Kulup Sastra Lisan Dayak Kanayaktn," dalam Rahimah A. Hamid (ed.), Kearifan Tempatan dari Lisan ke Aksara dan Media (Pulau Pinang: Penerbit USM, 2015),

18 Supriyanto, et. al., Islam and Local Wisdom: Religious Expression in Southeast Asia (Yogyakarta: Deepublish, 2018), 294. 
Maya Sopa pula menyatakan secara umum pembentukan kearifan tempatan dalam sesuatu masyarakat, menurut beliau ${ }^{19}$;

"Local wisdom is a set of ideas or polices based on the values of virtues found in a community and often applied, believed to be the guidance of life, and handed down from time to time. Based on the definitions, that local wisdom can be understood as a human effort by using their mind to act towards something, object, or events that occur in a certain space."

Berdasarkan pandangan ini, kearifan tempatan terbentuk melalui idea pemikiran atau sesuatu polisi dalam sesuatu masyarakat. Kemudian ia dipercayai, kerap dipakai dan sebahagiannya diwarisi. Menurut Gede Marhaendra, kearifan tempatan memiliki unsur-unsur tersebut ${ }^{20}$;

1. Alat ilmu pengetahuan

2. Wujud pada suatu komuniti

3. Sesuatu yang berasal dari generasi sebelum, atau;

4. Pengalaman berhubungan dengan kelompok lain (pengalaman sekarang)

5. Untuk menyelesaikan secara baik dan benar sesuatu persoalan dan kesulitan yang dihadapi

Sebahagian pengkaji cenderung memberi kefahaman yang sama antara kearifan tempatan (local wisdom), pengetahuan tempatan (local knowledge) dan kecerdikan setempat (local genius) antaranya seperti yang diutarakan oleh Wayan Rasna dan

19 Maya Sopa, "Local Wisdom in the Cultural Symbol of Indonesian Traditional House," dalam The 1st Annual International Conference on Language and Literature, 524-531 (Dubai: KnE Social Sciences, 2018), 524-525

20 Gede Marhaendra Wija Atmaja et. al., Pluralisme Konstitusional dalam Pengakuan Kesatuan Masyarakat Hukum Adat (Yogyakarta: ANDI, 2017), 16. 
Dewa Komang Tantra ${ }^{21}$ dan Adri Febrianto ${ }^{22}$. Namun terdapat juga pengkaji lain yang cuba membezakan ketiga-tiga perkara tersebut dengan mengutarakan kewujudan local wisdom adalah hasil gabungan local genius dan local knowledge. Kedua-dua pandangan ini tidak memberi kesan yang jelas dalam menjelaskan kedudukan kearifan tempatan secara teori. Kearifan tempatan adalah satu nilai dan falsafah sesuatu masyarakat atau kelompok kecil yang dilihat baik dan terbukti keberkesanannya sama ada dari sudut pemikiran, perbuatan, percakapan, nilai rohani dan kepercayaan.

\section{RUANG LINGKUP PERBINCANGAN KEARIFAN TEMPATAN}

Secara umumnya, kearifan tempatan ini boleh diterjemahkan dalam bentuk pelbagai seperti (1) kata pepatah berbentuk nasihat, pantun, syair, cerita lisan atau (2) sistem, prinsip, norma, aturan sosial dan moral yang menjadi satu sistem sosial, upacara, kepercayaan, amalan ritual dan tradisi atau (3) perlakuan dan tindakan dalam interaksi sosial. Selain itu, ia merangkumi (4) benda yang berbentuk fizikal seperti wayang dan joglo (rumah tradisional jawa) ${ }^{23}$.

Kerana itulah Patta Rapanna menjelaskan bahawa kearifan tempatan ini merupakan suatu nilai dari leluhur yang tidak boleh dibancangkan kandungan nilainya ${ }^{24}$. Hal yang sama ditegaskan oleh Mungmachon bahawa kearifan tempatan mempunyai ciri abstrak atau tidak abstrak (konkrit), namun begitu ciri paling utama

21 Wayan Rasna \& Dewa Komang Tantra, "Reconstruction of Local Wisdom for Character Education through the Indonesia Language Learning: An Ethno-pedagogical Methodology," Theory and Practice in Language Studies 7, 12 (2017): 1229-1235, 1229.

22 Adri Febrianto, Antropologi Ekologi: Suatu Pengantar (Jakarta: KENCANA, 2016), 110.

23 Irawan Satria Purwanto, "Nilai-Nilai "Dharma" Teks Cerita Mahabarata Versi Novel Karya R. K. Narayan”. (Disertasi Sarjana Pendidikan Bahasa dan Sastra Indonesia, Universitas Muhammadiyah Malang, 2017), 16-17.

24 Patta Rapanna, Membumikan Kearifan Lokal dalam Kemandirian Ekonomi (Makassar: CV Sah Media, 2016), 86. 
adalah kearifan tempatan lahir dari pengalaman atau kebenaran kehidupan. Kearifan dari pengalaman nyata berintegrasi dengan badan, rohani dan persekitaran. Juga kesan daripada sikap hormat kepada generasi tua termasuk pengalaman hidup mereka ${ }^{25}$.

Dalam kajian-kajian mengenai kearifan tempatan membuktikan ruang lingkup dan bentuk kearifan tempatan tersebut. Sebagai contoh, Feddy Hendrawan yang mengkaji kearifan tempatan dalam binaan arkitek serta rekaan dalaman berasaskan empat konsep iaitu Vaastu Shastra, Feng Shui, Zen dan Asta Kosala Kosali ${ }^{26}$. Begitu juga Mira Zulia Suriastuti, Deddy Wahjudi dan Bagus Handoko yang melihat elemen kearifan tempatan dalam pelan binaan arkitek di Bandung ${ }^{27}$. Bachtiar Fauzy pula melakukan kajian mengenai elemen kearifan tempatan dalam binaan rumah tinggal masyarakat Kota Pesisir Utara Jawa. Kearifan tempatan tersebut boleh dilihat dari fungsi bentu dan makna binaan tersebut ${ }^{28}$.

Normadiah, et. al. mengkaji elemen kearifan tempatan dalam memorat perubatan tradisional Etnik Murut Tahol ${ }^{29}$. Kemudian, kajian Remmy, et. al. yang mengkaji "Padi" dalam kearifan

25 Mungmachon, Miss Roikhwanphut, "Knowledge and Local Wisdom: Community Treasure," International Journal of Humanities and Social Science 2, no. 13 (2012), 176.

26 Freddy Hendrawan, "Kearifan Lokal dalam Arsitektur dan Desain Interior: Studi Komparasiempat Konsep di Asia," Jurnal Desain Interior III, 1 (2016), 69-85.

27 Mira Zulia Suriastuti, Deddy Wahjudi \& Bagus Handoko, "Kajian Penerapan Konsep Kearifan Lokal Pada Perancangan Arsitektur Balaikota Bandung." Jurnal Itenas Rekarupa 1, no. 2 (2014), 122128.

28 Bachtiar Fauzy, "Konsep Kearifan Lokal dalam Arsitektur Rumah Tinggal Masyarakat Kota Pesisir Utara Jawa Kasus Studi: Arsitektur Rumah Tinggal di Kampung Sumber Girang - Lasem," Research Report-Engineering Science 1 (2012): 1-53.

29 Normadiah N., et. al., "Unsur Kepercayaan dan Kearifan Tempatan dalam Memorat Perubatan Tradisional Etnik Murut Tahol di Sabah," Kemanusiaan 24, 2 (2017): 59-88. 
tempatan masyarakat Iban ${ }^{30}$. Selanjutnya kajian Ahmad Zulman, Badaruddin dan Siti Naquiah yang mengkaji taraf sosioekonomi nelayan Beserah, Pahang berasaskan teknik tangkapan hasil laut warisan turun temurun ${ }^{31}$. Mohammad Zohir dan Noorazlina pula mengkaji mengenai pengetahuan guru geografi terhadap kearifan tempatan berkait alam sekitar ${ }^{32}$. Jamal Rizal dan Imaduddin pula mengkaji mengenai dialek keturunan Tok Linggi di Pahang dalam kerangka kearifan tempatan ${ }^{33}$.

Dalam perencanaan ruang sesuatu kawasan juga boleh melibatkan kearifan tempatan, rencana dan perancangan tersebut melibatkan ketenteraan, tempat ibadah, mahkamah, pentadbiran kerajaan dan pasar atau pusat ekonomi. Hal ini cuba ditonjolkan oleh Rachmad Safa'at, et. al. ${ }^{34}$ dan Indarti Komala Dewi dalam kajian mereka ${ }^{35}$. Justeru, apa yang ditegaskan sebelum ini jelas

30 Remmy, G., Rosnah, Mustafa, Hamidah A. W. and Wan Robiah M. O. \& Siti Marina K., "Kearifan tempatan: Deskripsi dan Terminologi tentang 'Padi' dalam masyarakat Iban di Sarawak." In: The International Conference on Language Studies 2017 (iCLS 2017), 9th and 10th August 2017, Riverside Majestic Hotel, Kuching, Sarawak, Malaysia.

31 Ahmad Zulman M. Z., Badaruddin M. \& Siti Naquiah A., "Nelayan dan Penangkapan Hasil Laut: Satu Teknik Kearifan Tempatan di Beserah, Pahang”. dalam: Nazarudin Zainon (Ed.), Antropologi dan Sejarah dalam Kearifan Tempatan (Pulau Pinang: Penerbit USM, 2015).

32 Mohammad Zohir A. \& Noorazlina S., "Pengetahuan Tentang Kearifan Tempatan Berkait Alam Sekitar dalam Kalangan Guru Geografi," Geografi 4, 2(2016): 1-8.

33 Jamal Rizal R. \& Imaduddin A., "Dialek Keturunan Tok Linggi dalam Kerangka Kearifan Tempatan," International Journal of Humanities Technology and Civilization (IJHTC) 1, no. 2 (2016), 92-105.

34 Rachmad Saf'at, et. al., "The Spatial Planning Based on Local Wisdom of the Customary Legal Community in Aceh," Journal of Law, Policy and Globalization 54 (2016), 147-151.

35 Indarti Komala Dewi, "Local Wisdom in Spatial Planning as an Adaptation Form Toward the Disaster (Case Study: Naga Village in Tasikmalaya District, West Java Province, Indonesia)," Kertas kerja, Conference: $13^{\text {th }}$ International Congress of Asian Planning Schools Association (APSA 2015), di Universiti Teknologi Malaysia, Johor Bahru, 241-242. 
telah ditonjolkan dalam banyak kajian kearifan tempatan, iaitu elemen nilai, idea dan falsafah yang lahir dari integrasi manusia dan persekitaran, pengalaman, ujian dan perasaan hormat lalu diterjemahkan dalam bentuk pemikiran, kepercayaan, nilai rohani, perbuatan dan percakapan.

\section{KEARIFAN TEMPATAN DALAM PERSPEKTIF HUKUM ISLAM}

Terdapat dua persoalan utama dalam kajian ini yang perlu dititik beratkan iaitu adakah kearifan tempatan ini wujud dalam nas syarak? Dan kedua apakah kedudukan kearifan tempatan dalam hukum Islam? Persoalan ini sudah tentu dapat dijelaskan dengan merujuk kepada al-Quran dan hadis Nabi SAW di samping kitabkitab fiqh. Perkara pertama yang perlu dijelaskan adalah adakah kearifan tempatan itu boleh diposisikan sebagai uruf dalam pembendaharaan usul fiqh?

Dalam al-Ta'rifat, al-Jurjani menjelaskan uruf sebagai ${ }^{36,}$

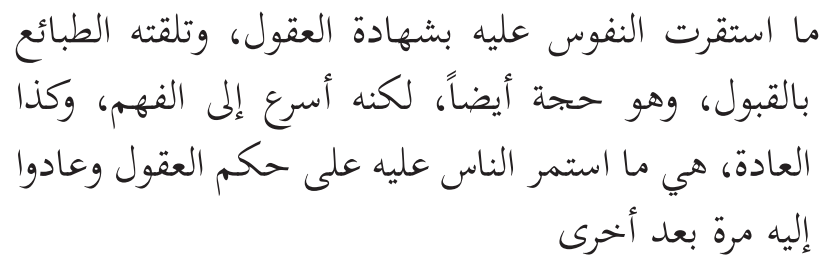

Terjemahan: Apa yang diperakui oleh diri berserta kesaksian akal, dan selaras dengan penerimaan tabiat manusia, ia merupakan hujah bahkan ia lebih segera untuk difahami, begitu juga halnya adat, iaitu apa yang diterima oleh manusia bersandarkan hukum akal dan sentiasa mengulangi perbuatan tersebut.

Jadi uruf adalah sesuatu yang diterima oleh akal dan tabiat manusia, namun apakah yang dimaksudkan dengan sesuatu dalam pengertian ini. Jika merujuk kepada Mu'jam Lughah al-Fuqaha' uruf bermakna adat orang kebanyakan dalam sesuatu kaum dalam

36 'Alī bin Muḥammad al-Jurjānī, al-Ta'rifat, 193. 
aspek perbuatan dan percakapan ${ }^{37}$. Manakala menurut al-Zuhaylī, uruf adalah apa yang manusia sering lakukan hingga menjadi adat dan ia tersebar dalam kalangan manusia pada sesuatu perbuatan atau satu lafaz yang difahami ketika diutarakan dengan makna khas yang berbeza dengan makna yang lazim difahami ketika didengari ${ }^{38}$. Justeru, uruf dalam konteks ini melibatkan perbuatan dan perkataan. Bahkan, uruf adalah melibatkan amalan atau perkataan kebanyakan orang pada suatu kawasan yang berbeza dengan adat yang boleh berlaku dengan perbuatan golongan minoriti ${ }^{39}$.

Sebagaimana dijelaskan bahawa kearifan tempatan tidak hanya terhad kepada perbuatan dan percakapan sahaja, oleh itu, uruf dilihat bukan satu terjemahan yang tepat kepada kearifan tempatan. Dari perspektif luasnya pemakaian dalam kalangan masyarakat, kearifan tempatan dilihat sama seperti konsep adat kerana diterima walaupun hanya dalam kalangan individu atau minoriti. Tetapi adat juga terhad kepada perbuatan dan percakapan sehingga masih lagi tidak tepat untuk menjelaskan makna kearifan tempatan.

Lantaran itu, daripada konsep yang telah dijelaskan kearifan tempatan boleh ditakrifkan sebagai hikmah atau al-hikmah almahaliyyah. Tinggal lagi persoalan apakah kedudukan hikmah ini di dalam hukum Islam. Jika merujuk di dalam al-Quran, perkataan hikmah banyak disebut dan kebanyakan daripadanya ditafsirkan sebagai al-Sunnah ${ }^{40}$. Namun, perkataan hikmah pada ayat alQuran sebagaimana firman Allah SWT dalam surah al-Baqarah;

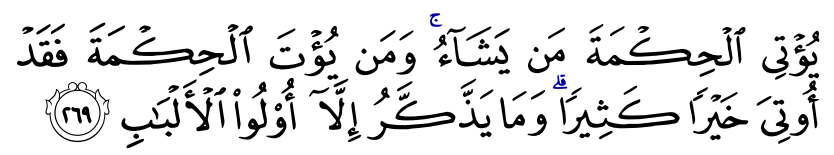

Terjemahan: Allah memberikan Hikmah kebijak-

37 Muhammad Qal'aji, Mu'jam Lughah al-Fuqaha' (Bayrūt: Dār alNafa'is, 1988), 309.

38 Wahbah al-Zuhaylī, Ușūl al-Fiqh al-Islāmī (Dimashq: Dār al-Fikr, 2010), 2: 104 .

39 Mustafa Ahmad al-Zarqa, Al-Madkhal al-Fiqhi al-'Am (Dimashq: Dār al-Qalam, 2004), 874.

40 Jalal al-Din al-Suyuti, Tadrib al-Rawi fi Sharh Taqrib al-Nawawi (Bayrūt: Dār al-Kutub al-'Ilmiyyah, 1996), 1: 25. 
sanaan (ilmu yang berguna) kepada sesiapa yang dikehendaki-Nya (menurut aturan yang ditentukanNya). Dan sesiapa yang diberikan hikmah itu maka sesungguhnya ia telah diberikan kebaikan yang banyak. Dan tiadalah yang dapat mengambil pengajaran (dan peringatan) melainkan orang-orang yang menggunakan akal fikirannya.

(Surah al-Baqarah, 2: 269)

Hikmah dalam ayat tersebut tidak ditafsirkan dengan makna al-sunnah, namun ia ditafsirkan dengan pelbagai tafsiran ${ }^{41}$. Dalam banyak penafsiran tersebut, al-Razi mengemukakan pandangan bahawa makna hikmah dalam ayat tersebut tidak terkeluar dari dua maksud, ini kerana kesempurnaan manusia juga pada dua perkara iaitu; mengetahui kebenaran pada zat sesuatu dan mengetahui kebaikan untuk tujuan beramal dengannya. Perkara pertama itu mengandungi ilmu dan pengetahuan yang sesuai dan kedua mengandung perbuatan adil dan betul ${ }^{42}$.

Menariknya, kefahaman hikmah yang merangkumi nilai intelektual, falsafah pemikiran dan tindakan serta perbuatan banyak diutarakan oleh ulama'. Al-'Asqalān̄̄ contohnya menjelaskan sabda Nabi SAW;

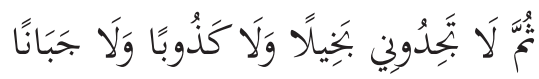

Terjemahan: kemudian kamu tidak mendapati aku seorang yang kededut, penipu dan penakut.

(Hadis riwayat al-Tabarani)

Maksud tidak takut adalah kesempurnaan kekuatan kemarahan yang diertikan sebagai berani, manakala tidak menipu adalah kesempurnaan kekuatan akal yang diertikan sebagai hikmah

41 Salman bin Umar al-Sanidi, Tadabbur al-Qur 'an (Riyāḍ: Majallah al-Bayan, 2002), 106.

42 Fakhr al-Dīn Muhammad al-Razī, Mafātih al-Ghayb (Dimashq: Dār al-Fikr, 1981), 73. 
dan tidak kedekut adalah kesempurnaan kekuatan syahwat yang diertikan sebagai pemurah ${ }^{43}$.

Berkait dengan kearifan tempatan, terdapat hadis Nabi SAW yang menjelaskan tentang satu konsep yang dilihat selari dengan kearifan tempatan yang disebut hikmah dan kemudian disandarkan dengan tempat (al-hikmah al-mahalliyah). Perkataan hikmah ini digandingkan dengan satu tempat iaitu negeri Yaman (atau salah satu kawasan di Yaman). Sabda Rasulullah SAW:

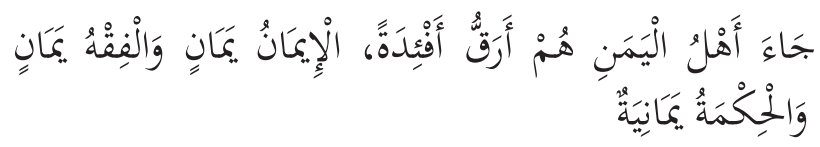

Terjemahan: Telah datang penduduk Yaman, mereka adalah kaum yang paling lembut hatinya. Iman itu ada di negeri Yaman, fiqh itu ada di negeri Yaman dan hikmah itu ada pada orang Yaman.

(Hadis riwayat al-Bukhari dan Muslim)

Al-'Asqalānī dan al-Nawawi menjelaskan makna hikmah dalam hadis tersebut sebagai ilmu yang holistik terhadap pengetahuan tentang Allah SWT berserta pandangan yang lengkap, penyucian diri, merealisasikan tindakan (amalan) terhadap pengetahuan tersebut dan menahan diri daripada tindakan bercanggah ${ }^{44}$. Di samping itu, makna hikmah ini adalah disebut berasingan dengan perkataan fiqh yang membawa erti kefahaman dan iman yang membawa keyakinan. Tambahan pula, perkataan hikmah digandingkan dengan Yaman yang menguatkan wujudnya ciri kearifan tempatan.

Selain itu, terdapat hadis Nabi SAW yang menyatakan syair itu sebagai suatu bentuk hikmah, sabda Baginda SAW;

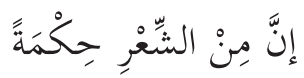

43 Ahmad bin 'Ali bin Hajar al-'Asqalānī, Fath al-Bārī bi Sharh Ṣah̄ịh al-Bukhārī (Riyāạ: Dār Ṭayyibah, 2005), 8: 210.

44 Al-'Asqalānī, Fath al-Bārē bi Sharh Șah̄ịh al-Bukhārī, 2: 53; alNawawī, Sahịḥ bi Sharh al-Nawawì (Qāhirah: Muasasah Qurțubah, 1994), 2: 44 
Terjemahan: Sesungguhnya pada sya 'ir itu ada hikmah.

Ia membawa maksud syair itu adalah perkataan yang jujur dan selari dengan kebenaran ${ }^{45}$. Menurut al-'Azim Abadi, maksud pada syair itu ada hikmah adalah padanya ada kebenaran, perkataan yang jujur selari dengan hak. Dikatakan asal kepada hikmah adalah mencegah, jadi syair adalah satu perkataan yang bermanfaat dan mencegah dari kebodohan ${ }^{46}$. Sastera lisan juga pada asasnya merupakan satu bentuk kearifan tempatan contohnya alam melayu yang mempunyai pantun, gurindam, seloka dan seumpamanya.

Perkara kearifan tempatan ini juga boleh dilihat dalam sirah Nabi SAW, ketika peristiwa perang Khandaq di mana sahabat Salman al-Farisi memberi buah fikiran supaya digali parit bagi menghadapi musuh dari kalangan Quraisy. Buah fikiran ini adalah sebuah kearifan tempatan yang diaplikasikan orang Parsi sebagai salah satu strategi menentang musuh khususnya tentera berkuda. Rasulullah SAW juga menerima cadangan Salman al-Farisi tersebut ${ }^{47}$.

Pada hakikatnya serapan nilai kearifan tempatan sewaktu zaman Nabi perlu digali, contohnya dari sudut strategi peperangan seperti perang Uhud, kedudukan masyarakat (persaudaraan), sistem ' $a q i l a h^{48}$ dan sebagainya. Hal ini ditegaskan juga oleh Abdul Mukti bahawa pemerintahan Madinah sewaktu zaman Baginda Rasulullah SAW dianggap sebagai satu karya politik

45 Muḥammad 'Abd al-Raḥmān al-Mubārakfurī, Tuḥfah al-Aḥwadh̄̄ (Dimashq: Dār al-Fikr, t.t.), 8: 135.

46 Al-'Aẓ̄im Abādī Ab̄̄ 'Abd Allāh al-Rahmān Sharf al-Haq Muḥammad Ashrāf al-Sidik̄̄, 'Awn al-Ma 'būd Sharḥ al-Sunan Ab̄̄ Dāiud ('Ammān: Bayt al-Afkār al-Duwaliyah, t.t.), 2150.

47 'Abd al-Qadir Syaybah al-Hamd, Fiqh al-Islam Sharh Bulugh alMaram (al-Madinah: Matabi’ al-Rasyid, 1982), 5: 195.

48 Kamaruddin Sharif \& Wang Yong Bao, "Theory and Instruments of Social Safety Nets and Social Insurance in Islamic Finance: Takaful and Ta'min," dalam Zamir Iqbal \& Abbas Mirakhor (eds.), Economic Development and Islamic Finance, 231-251 (Washington: The World Bank, 2016), 243. 
yang sempurna. Hal ini adalah kerana gabungan perpaduan antara nilai kearifan tempatan dan ajaran Islam ${ }^{49}$.

Secara umumnya kita dapati bahawa kearifan tempatan ini tidak boleh dikatakan asing dalam Islam. Lanjutan itu, perkara yang menjadi fokus adalah kedudukannya berasaskan perspektif hukum Islam. Kesimpulan pertama yang dapat dibuat berasaskan kenyataan dan idea yang telah dikemukakan mendapati kearifan tempatan adalah lebih umum berbanding uruf dan adat. Jadi secara asasnya hubungan kearifan tempatan dengan uruf dapat dijelaskan sebagaimana jadual berikut:

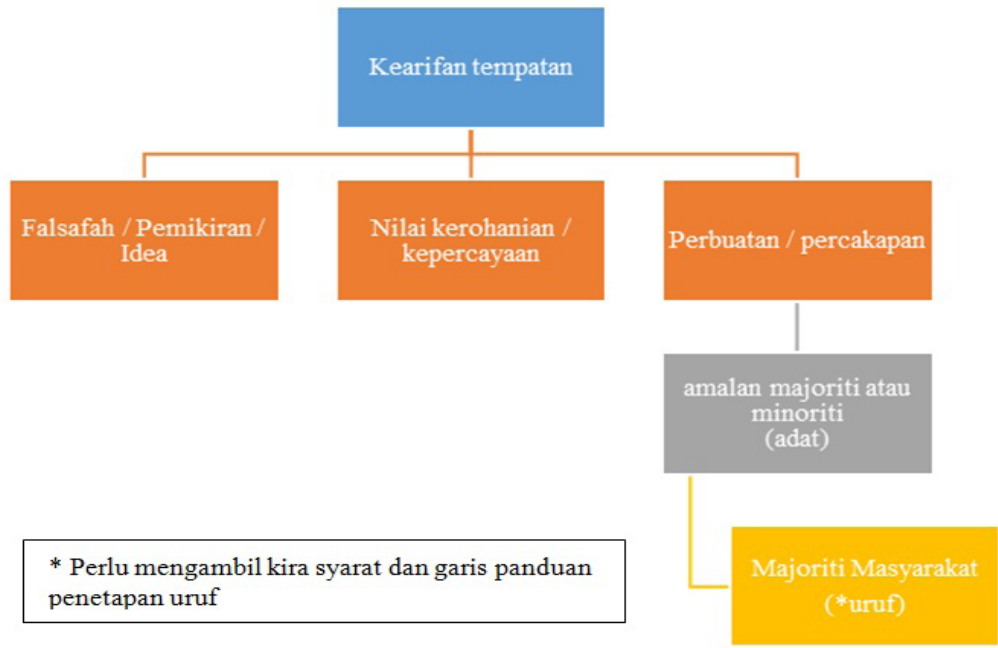

Falsafah, pemikiran dan idea adalah seperti ilmu bintang orang asli Semelai ${ }^{50}$, ilmu pengurusan lombong terbiar ${ }^{51}$, falsafah

49 Abdul Mukti Thabrani, "Tata Kelola Pemerintahan Negara Madinah Pada Masa Nabi Muhammad SAW," Jurnal Agama dan Hak Asasi Manusia 4, no. 1 (2014), 21.

50 Nurul Fatini Jaafar, "Ilmu Langit Orang Asli - Khazanah yang Dilupakan" (makalah Program Bicara @ Muzium pada 15 Ogos 2017 di Auditorium Muzium Negara, Kuala Lumpur).

51 Wahyudi Himawan, Fachrurrozie Sjarkowie \& Alfitri, "Local Wisdom from the Socio-Ecological Perspectives: Managing Former Mine Lands in Achieving Green Era," IOSR Journal of Humanities and Social Science 19, no. 12 (2014), 52-57. 
pembinaan atau reka bentuk umah edet pitu ruang Gayo ${ }^{52}$. Nilai kerohanian dan kepercayaan pula contohnya kepercayaan terhadap mimpi, pelbagai jenis semangat ghaib serta haiwan tertentu yang dianggap dapat membantu mereka mengubati penyakit rohani ${ }^{53}$ dan kepercayaan makhluk halus dan roh $^{54}$. Manakala perbuatan dan percakapan yang dalam katagori adat dan uruf seperti wayang kulit, mandi safar, amalan perbidanan Melayu dan seumpamanya.

Justeru dalam penentuan kearifan tempatan dalam hukum Islam adalah masih mengambil kira kaedah-kaedah dan prinsipprinsip umum. Hal ini adalah berlandaskan kepada beberapa hadis yang boleh dijadikan sandaran. Sabda Nabi SAW;

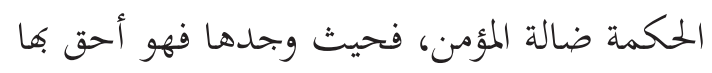

Terjemahan: Hikmah itu merupakan barang hilang orang Mukmin, di mana dia mendapatinya maka dia berhak terhadapnya.

(Hadis riwayat al-Tirmidhi dan Ibn Majah)

Walaupun hadis ini mempunyai pertikaian dari sudut sanad, namun dari sudut kefahaman bahawa hikmah itu adalah sesuatu yang harus untuk diterima pakai dalam Islam. Hadis ini membawa makna sekiranya orang yang bijak pandai mencari satu hikmah atau kebijaksanaan, lalu menjumpainya maka dia berhak terhadap hikmah tersebut. Boleh juga difahami bahawa hikmah itu tidak berada pada orang yang layak, namun jika orang yang layak mendapatinya maka hikmah itu lebih berhak untuknya ${ }^{55}$. Begitu juga sebuah hadis Nabi SAW;

52 Maya Sopa, "Local Wisdom in the Cultural Symbol of Indonesian Traditional House," 525.

53 Normadiah N., et. al., "Unsur Kepercayaan dan Kearifan Tempatan dalam Memorat Perubatan Tradisional Etnik Murut Tahol di Sabah," 59.

54 Awang Azman Awang Pawi, "Weltanschauung dan Manifestasi Kepercayaan Tradisi Etnik di Sarawak", Melayu: Jurnal Antarabangsa Dunia Melayu 6, no. 2 (2013), 139-154.

55 'Ali bin Sultan Muhammad al-Qari, Mirqat al-Mafatih Sharh Misykat al-Masabih (Bayrūt; Dār al-Kutub al-'Ilmiyyah, 2001), 1: 433. 


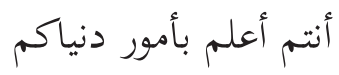

Terjemahan: Kamu lebih mengetahi tentang urusan dunia kamu.

(Hadis riwayat Ibn Khuzaimah)

Hadis ini disabdakan Baginda SAW bersandarkan satu peristiwa, iaitu ketika mana Baginda melalui satu kelompok masyarakat yang sedang mengacuk pohon tamar (bagi menjadikan buah yang terhasil elok). Baginda menegur bahawa jika pohon itu tidak dikacuk nescaya buahnya juga akan elok. Namun, apabila mereka mengikuti teguran itu dan mendapati hasilnya adalah rosak. Justeru Baginda SAW menyatakan bahawa urusan dunia ini lebih difahami oleh mereka namun urusan agama adalah dalam pengetahuan Baginda Rasul ${ }^{56}$.

Justeru, kedudukan kearifan tempatan selagi mana tidak menjejaskan prinsip akidah dan keimanan, tidak merosakkan akal, tidak menimbulkan mafsadah serta tidak jelas bercanggah dengan nilai-nilai Syariah ia boleh dikategorikan sebagai harus. Hal ini berasaskan kepada perbincangan asas kepada sesuatu adalah harus selagi mana tidak ada petunjuk yang membawanya kepada hukum lain ${ }^{57}$. Namun begitu, perlu difahami juga bahawa sesuatu perkara harus itu secara umunya tidak akan kekal kedudukannya sebagai harus, ia akan ditarik oleh hukum-hukum yang lain.

Sekiranya kearifan tempatan menepati syarat uruf, maka ukuran yang akan digunakan dalam menentukan uruf sahih dan uruf fasid adalah berasaskan kerangka perbincangan uruf dalam usul fiqh. Kemudian kedudukannya sebagai penentu dalam keputusan hukum juga adalah sebagaimana yang dibahaskan dalam perbincangan usul fiqh.

\section{KESIMPULAN}

Kajian ini telah mengemukakan konsep kearifan tempatan dalam

56 Muhammad Hasan bin 'Aqil Musa, al-Mukhtar al-Masun min A'lam al-Qurun (Jeddah: Dār al-Andalus al-Khadra', t.t.), 1858.

57 Salih Ghanim al-Sadlan, al-Qawaid al-Fiqhiyyah al-Kubra wa ma Tafarru' 'Anha (Riyāḍ: Dār al-Balinsiah, 1418H), 126. 
beberapa kajian lepas. Konsep tersebut telah diselarikan dengan perbahasan Bahasa Arab kemudian digarap berasaskan perspektif hukum Islam. Lantaran itu, didapati bahawa kearifan tempatan bukanlah secara mutlak diposisikan sebagai uruf. Bahkan ia adalah bersifat umum yang meliputi beberapa perkara seperti falsafah, idea dan pemikiran, nilai kerohanian dan kepercayaan dan amalan serta percakapan. Jadi gabungan ukuran akidah, syariah dan akhlak perlu dilakukan dalam menentukan kedudukan kearifan tempatan yang berlansung dalam kalangan masyarakat. Justeru, kajian lanjut bagi mendokong teori ini dan menjadikanya sebagai satu asas konseptual yang kukuh perlulah dilakukan.

\section{RUJUKAN}

'Abd al-Hakim al-Ramili. Taghayyur al-Fatwa fi al-Fiqh alIslāmī. Bayrūt: Dār al-Kutub al-'Ilmiyyah, 2016.

'Abd al-Qadir Syaybah al-Hamd. Fiqh al-Islam Sharh Bulugh alMaram. Al-Madinah: Matabi' al-Rasyid, 1982.

'Al̄̄ bin Muḥammad al-Jurjānī. Al-Ta'rifat. Qāhirah: Dār alRayyān li al-Turāth, t.t.

'Ali bin Sultan Muhammad al-Qari. Mirqat al-Mafatih Sharh Misykat al-Masabih. Bayrūt: Dār al-Kutub al-'Ilmiyyah, 2001.

Al-'Aẓīm Abādī Abī 'Abd Allāh al-Rahmān Sharf al-Ḥaq Muhammad Ashrāf al-Sidikī, 'Awn al-Ma 'būd Sharh alSunan Abī Dāwud ('Ammān: Bayt al-Afkār al-Duwaliyah, t.t.).

Abdul Mukti Thabrani. "Tata Kelola Pemerintahan Negara Madinah Pada Masa Nabi Muhammad SAW." Jurnal Agama dan Hak Asasi Manusia 4, no. 1 (2014), 13-30.

Ackoff, R. L. "From data to wisdom." Journal of Applied Systems Analysis 15 (1989), 3-9.

Adri Febrianto. Antropologi Ekologi: Suatu Pengantar. Jakarta: KENCANA, 2016.

Ahmad bin 'Ali bin Hajar al-'Asqalānī. Fath al-Bārī bi Sharh Șaḥịh al-Bukhārī. Riyāḍ: Dār Ṭayyibah, 2005. 
Ahmad Zulman M. Z., Badaruddin M. \& Siti Naquiah A. "Nelayan dan Penangkapan Hasil Laut: Satu Teknik Kearifan Tempatan di Beserah, Pahang." dalam: Nazarudin Zainon (ed.), Antropologi dan Sejarah dalam Kearifan Tempatan. Pulau Pinang: Penerbit USM, 2015.

As'ad 'Abd al-Ghani al-Kafrawi. Al-Istidlal 'inda al-Usuliyyin. Qāhirah: Dār al-Salam, 2002.

Awang Azman Awang Pawi. "Weltanschauung dan Manifestasi Kepercayaan Tradisi Etnik di Sarawak." Melayu: Jurnal Antarabangsa Dunia Melayu 6, no. 2 (2013), 139-154.

Azkia Muharom Albantani \& Ahmad Madkur. "Think Globally, Act Locally: The Strategy of Incorporating Local Wisdom in Foreign Language Teaching in Indonesia." International Journal of Applied Linguistics \& English Literature 7, no. 2 (2018), 1-8.

Bachtiar Fauzy. "Konsep Kearifan Lokal dalam Arsitektur Rumah Tinggal Masyarakat Kota Pesisir Utara Jawa Kasus Studi: Arsitektur Rumah Tinggal di Kampung Sumber Girang Lasem." Research Report-Engineering Science 1 (2012): 1- 53.

Fakhr al-Dīn Muḥammad al-Razī. Mafätih al-Ghayb. Dimashq: Dār al-Fikr, 1981.

Freddy Hendrawan. "Kearifan Lokal dalam Arsitektur dan Desain Interior: Studi Komparasiempat Konsep di Asia." Jurnal Desain Interior III, 1 (2016), 69-85.

G. Donald Allen. "Hierarchy of Knowledge: From Data to Wisdom." International Journal of Current Research in Multidisciplinary (IJCRM) 2, no. 1 (2017), 15-23.

Gede Marhaendra Wija Atmaja et. al. Pluralisme Konstitusional dalam Pengakuan Kesatuan Masyarakat Hukum Adat. Yogyakarta: ANDI, 2017.

Ibn al-Qayyim al-Jawziyyah. Madarij al-Salikin Bayna Manazil Iyyaka Na'bud wa Iyyaka Nasta'in. Dimashq: Dār al-Kitab al-'Arabī, 1996. 
Indarti Komala Dewi. "Local Wisdom in Spatial Planning as an Adaptation Form Toward the Disaster (Case Study: Naga Village in Tasikmalaya District, West Java Province, Indonesia)." Kertas kerja, Conference: $13^{\text {th }}$ International Congress of Asian Planning Schools Association (APSA 2015), di Universiti Teknologi Malaysia, Johor Bahru.

Indrayuda. "The Existence of Local Wisdom Value Through Minangkabau Dance Creation Representation in Present Time." HARMONIA: Journal of Arts Research and Education 16, no. 2 (2016), 143-152.

Irawan Satria Purwanto. "Nilai-Nilai "Dharma" Teks Cerita Mahabarata Versi Novel Karya R. K. Narayan". Disertasi Sarjana Pendidikan Bahasa dan Sastra Indonesia, Universitas Muhammadiyah Malang, 2017.

Jalal al-Din Al-Sayuti. Mu'jam Maqalid al- 'Ulum fi al-Hudud wa al-Rusum. Qāhirah: Maktabah al-Adab, 2004.

Jalal al-Din al-Suyuti. Tadrib al-Rawi fi Sharh Taqrib al-Nawawi. Bayrūt: Dār al-Kutub al-'Ilmiyyah, 1996.

Jamal Rizal R. \& Imaduddin A. "Dialek Keturunan Tok Linggi dalam Kerangka Kearifan Tempatan.” International Journal of Humanities Technology and Civilization (IJHTC) 1, no. 2 (2016), 92-105.

Jubran Mas'ud. Al-Raid: Mu'jam Lughawiyy 'Asriyy. Bayrūt: Dār al-'Ilm li al-Malayin, 1996.

Jundiani. "Local Wisdom in the Environmental Protection and Management." dalam IOP Conf. Series: Earth and Environmental Science 175. UK: IOP Publishing, 2018, 1-5.

Kamaruddin Sharif \& Wang Yong Bao. "Theory and Instruments of Social Safety Nets and Social Insurance in Islamic Finance: Takaful and Ta'min." Dalam Zamir Iqbal \& Abbas Mirakhor (eds.), Economic Development and Islamic Finance, 231- 251. Washington: The World Bank, 2016.

Liu, J. K-C. "When Professional Knowledge Meets Local Wisdom: A Dilemma in Trans-Cultural Participatory Design." dalam Hou, J., Farncis, M. \& Brightbill, N. (eds.). (Re)constructing Communities Design Participation in the Face of Change, 41-46. Davis: Centre for Design Research, 2005. 
Maya Sopa. "Local Wisdom in the Cultural Symbol of Indonesian Traditional House." dalam The 1st Annual International Conference on Language and Literature, 524-531. Dubai: KnE Social Sciences, 2018.

Mike Watts, "Explanations and Explaining in Science: You Can't Force People to Understand," in Mike Watts, Debate in Science Education (New York: Routledge, 2014).

Mira Zulia Suriastuti, Deddy Wahjudi \& Bagus Handoko. "Kajian Penerapan Konsep Kearifan Lokal Pada Perancangan Arsitektur Balaikota Bandung." Jurnal Itenas Rekarupa 1, no. 2 (2014), 122-128.

Mohammad Zohir A. \& Noorazlina S. "Pengetahuan Tentang Kearifan Tempatan Berkait Alam Sekitar dalam Kalangan Guru Geografi." Geografi 4, 2(2016): 1-8.

Muhammad Qal'aji. Mu'jam Lughah al-Fuqaha'. Bayrūt: Dār alNafa' is, 1988.

Mungmachon, Miss Roikhwanphut. "Knowledge and Local Wisdom: Community Treasure." International Journal of Humanities and Social Science 2, no. 13 (2012), 174-181.

Mustafa Ahmad al-Zarqa. Al-Madkhal al-Fiqhi al- 'Am. Dimashq: Dār al-Qalam, 2004.

Muḥammad 'Abd al-Raḥmān al-Mubārakfurī, Tuhfah al-Aḥwadhī. Dimashq: Dār al-Fikr, t.t.Muhammad Hasan bin 'Aqil Musa. Al-Mukhtar al-Masun min A'lam al-Qurun. Jeddah: Dār al-Andalus al-Khadra', t.t.

Al-Nawawī, Șaḥīh bi Sharḥ al-Nawawī. Qāhirah: Muasasah Qurțubah, 1994.

Normadiah N., et. al.. "Unsur Kepercayaan dan Kearifan Tempatan dalam Memorat Perubatan Tradisional Etnik Murut Tahol di Sabah." Kemanusiaan 24, 2 (2017): 59-88.

Nurul Fatini Jaafar. "Ilmu Langit Orang Asli - Khazanah yang Dilupakan”. Makalah Program Bicara@ Muzium pada 15 Ogos 2017 di Auditorium Muzium Negara, Kuala Lumpur.

Patta Rapanna. Membumikan Kearifan Lokal dalam Kemandirian Ekonomi. Makassar: CV Sah Media, 2016. 
Rachmad Saf'at, et. al. "The Spatial Planning Based on Local Wisdom of the Customary Legal Community in Aceh." Journal of Law, Policy and Globalization 54 (2016), 147151.

Remmy, G., Rosnah, Mustafa, Hamidah A. W. and Wan Robiah M. O. \& Siti Marina K. "Kearifan tempatan: Deskripsi dan Terminologi tentang 'Padi' dalam masyarakat Iban di Sarawak." dalam The International Conference on Language Studies 2017 (iCLS 2017), 9th and 10th August 2017, Riverside Majestic Hotel, Kuching, Sarawak, Malaysia.

Salih Ghanim al-Sadlan. Al-Qawa 'id al-Fiqhiyyah al-Kubra wa ma Tafarru' 'Anha. Riyāḍ: Dār al-Balinsiah, 1418H.

Salman bin Umar al-Sanidi. Tadabbur al-Quran. Riyāḍ: Majallah al-Bayan, 2002.

Sesilia Seli. "Tema, Amanat dan Kearifan Tempatan dalam Cerita Ne'Baruakng Kulup Sastra Lisan Dayak Kanayaktn.” dalam Rahimah A. Hamid (ed.), Kearifan Tempatan dari Lisan ke Aksara dan Media. Pulau Pinang: Penerbit USM, 2015.

Steingass, f. English-Arabic Dictionary for The Use of Both Travelers and Students. London: W.H. Allen \& CO, 1882.

Supriyanto, et. al.. Islam and Local Wisdom: Religious Expression in Southeast Asia. Yogyakarta: Deepublish, 2018.

Wahbah al-Zuḥaylī. Ușūl al-Fiqh al-Islāmī. Dimashq: Dār al-Fikr, 2010.

Wahyudi Himawan, Fachrurrozie Sjarkowie \& Alfitri. "Local Wisdom from the Socio-Ecological Perspectives: Managing Former Mine Lands in Achieving Green Era". IOSR Journal of Humanities and Social Science 19, no. 12 (2014), 52-57.

Wayan Rasna \& Dewa Komang Tantra. "Reconstruction of Local Wisdom for Character Education through the Indonesia Language Learning: An Ethno-pedagogical Methodology." Theory and Practice in Language Studies 7, no. 12 (2017): 1229- 1235. 